\title{
A Case Report of 3C Syndrome and Literature Review
}

\author{
Drissa Kanikomo1, Youssouf Sogoba1, Moussa Diallo1, Mamadou Salia Diarra², Oumar Coulibaly3, \\ Boubacar Sogoba1, Mahamadou Dama3, Mamady Coulibaly', Mamadou Diallo²
}

\author{
${ }^{1}$ Department of Neurosurgery, Gabriel Touré Teaching Hospital, Bamako, Mali \\ ${ }^{2}$ Department of Neurosurgery, Luxembourg Hospital, Bamako, Mali \\ ${ }^{3}$ Department of Neurosurgery, Hôpital du Mali, Bamako, Mali \\ Email: sogobayoussouf@yahoo.fr
}

How to cite this paper: Kanikomo, D., Sogoba, Y., Diallo, M., Diarra, M.S., Coulibaly, O., Sogoba, B., Dama, M., Coulibaly, M. and Diallo, M. (2022) A Case Report of 3C Syndrome and Literature Review. Case Reports in Clinical Medicine, 11, 8-12. https://doi.org/10.4236/crcm.2022.111002

Received: December 9, 2021

Accepted: January 10, 2022

Published: January 13, 2022

Copyright $\odot 2022$ by author(s) and Scientific Research Publishing Inc. This work is licensed under the Creative Commons Attribution International License (CC BY 4.0).

http://creativecommons.org/licenses/by/4.0/

\begin{abstract}
Ritscher-Schinzel syndrome, or 3C (cranio-cerebello-cardiac) syndrome is a developmental disorder characterized by cranio-facial, cerebellar and cardiac anomalies. It is a rare disease with an incidence of $1 / 1,000,000$ inhabitants, and was first described by Ritscher-Schinzel in 1987. 3C syndrome is an autosomal recessive disease caused by a mutation on the long arm of chromosome 8 to $8 \mathrm{q} 24.13$, the KIAA0196 locus, the strumpellin protein gene. The cardiac and cerebral anomalies are most often leading cause of death at an early age and people with $3 \mathrm{C}$ syndrome rarely exceed 40 years. In this paper, we report a case of Ritscher-Schinzel in 3-month-old boy who was admitted to our neurosurgical department in September 2020. Clinical examination revealed a macrocrania with head circumference at $47 \mathrm{~cm}$. There was a prominence of forehead and occiput, the root of the nose which was flat, hypertelorism and micrognatism. The CT scan revealed Dandy WALKER malformation with cystic dilation of the 4 th ventricle, an aplasia of the cerebellar vermis associated with a tretraventricular hydrocephalus.
\end{abstract}

\section{Keywords}

Cardiac Anomalies, Ritscher-Schinzel Syndrome, 3C

\section{Introduction}

Ritscher-Schinzel syndrome, or 3C (cranio-cerebello-cardiac) syndrome is a developmental disorder characterized by cranio-facial, cerebellar and cardiac anomalies [1] [2]. It is a rare disease with an incidence of $1 / 1,000,000$ inhabitants [3], and was first described by Ritscher-Schinzel in 1987. 3C syndrome is an autosomal recessive disease caused by a mutation on the long arm of chromosome 
8 to $8 \mathrm{q} 24.13$, the KIAA0196 locus [4], the strumpellin protein gene. The cardiac and cerebral anomalies are most often leading cause of death at an early age and people with $3 \mathrm{C}$ syndrome rarely exceed 40 years. In this paper, we report a case of Ritscher-Schinzel with literature review.

\section{Case Report}

First, this 3-month-old boy was admitted to our neurosurgical department in September 2020 for macrocrania and craniofacial dysmorphia. Clinical examination revealed a macrocrania with head circumference at $47 \mathrm{~cm}$. There was a prominence of forehead and occiput, the root of the nose which was flat, hypertelorism and micrognatism (Figure 1).

The CT scan (Figure 2) revealed Dandy WALKER malformation with cystic dilation of the 4 th ventricle, an aplasia of the cerebellar vermis associated with a tretraventricular hydrocephalus.

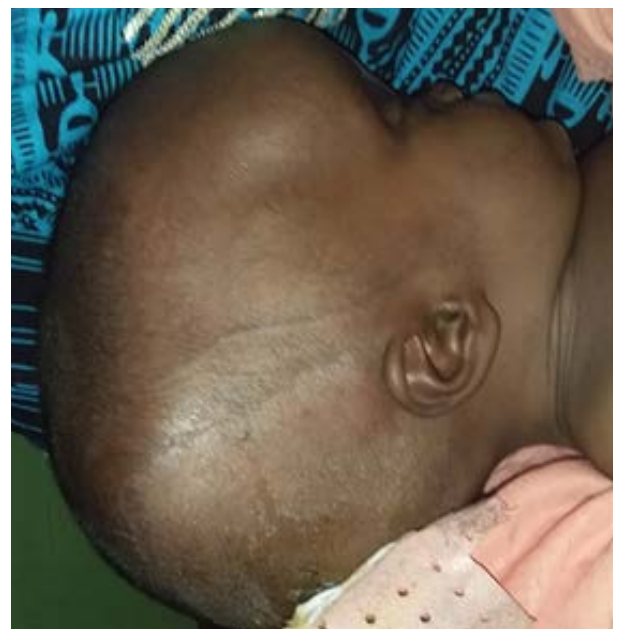

Figure 1. Clinical photograph showing the prominence of forehead and occiput, the flat root of the nose.

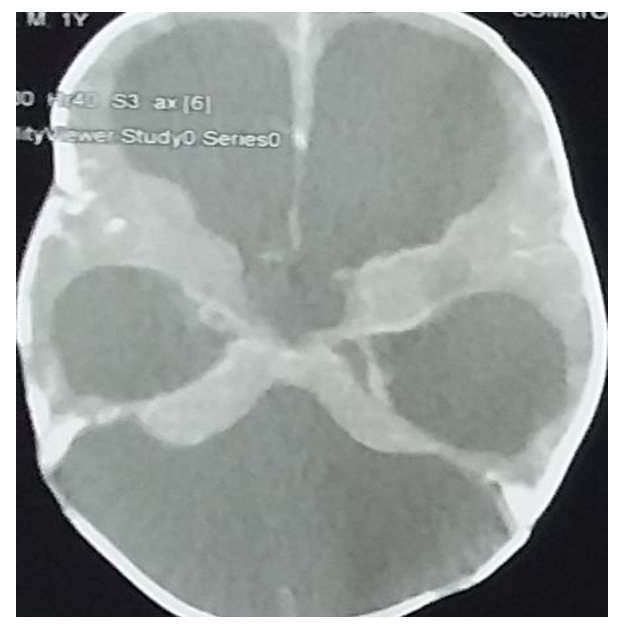

Figure 2. CT scan showing a cystic dilation of the 4th ventricle, an aplasia of the cerebellar vermis associated with hydrocephalus. 
A preoperative assessment was given and heart rhythm disturbances were discovered during the pre-anesthetic visit. A cardiac ultrasound performed revealed cardiac malformations such as: a single ventricle of the right type, absence of an interventricular membrane, a single cardiac atrium, stenosis of the pulmonary artery. Other cardiac abnormalities were noted: atresic left atrioventricular hemivalve, small leak on the right atrioventricular hemivalve. He was operated on 10/16/2020 for a ventriculo-peritoneal shunt. The post-operative course was uneventful and he was discharged from the hospital five days after surgery. He died suddenly at home without fever after surgery.

\section{Discussion}

$3 c$ syndrome is a rare malformation described since 1987 by Ritscher-Schinzel in two sisters [3]. The name Ritscher-Schinzel Syndrome was proposed in 1989 by Verloès et al. who described the third case [5]. This is an inherited autosomal recessive or $\mathrm{X}$-linked recessive disease with $<1 / 1,000,000$ (deepika) [6]. $t$ is characterized by the association of cranio-facial, cerebellar and cardiac abnormalities (Craft, Descipio C) [1] [2]. This malformation affects all ethnicities. There is significant variability in craniofacial anomalies and other associated malformations in the literature. Thus Leonardi et al. [2001] [7] suggested minimum clinical diagnostic criteria based on 28 affected individuals reported in the literature. They proposed that the following three criteria should all be met:

- Congenital cardiac malformation(s) other than the persistence of the ductus arteriosus alone.

- Dandy's malformation with hypoplasia of the cerebellar vermis or a mega-large cistern.

- Cleft palate or ocular coloboma or four of the following: prominent occiput and forehead, oblique eyelid fissures, widely spaced eyes depressed nasal bridge, micrognathia.

These criteria were present in our patient. At the cardiac level, our case presented a single heart with absence of the interventricular and interatrial septa, a stenosis of the pulmonary artery, an atresic left atrioventricular hemivalve, a small leak on the right atrioventricular hemivalve. In the literature, the septum defect is present in $68.7 \%$ according to PARADES [8] series of 26 cases and $82 \%$ of the 28 cases of $3 \mathrm{c}$ syndromes in the Leonardi study and valvular anomalies in $32 \%$ [7]. The true Dandy Walker malformation, constituting the second criterion of Ritscher Schinzel syndrome is more frequent (68\% of cases) than the Dandy Walker varying 21\% [7]. Isolated hydrocephalus is cited in $11 \%$ of $3 \mathrm{C}$ patients according to Konya [9], it was associated with the Dandy Walker malformation in our case. The polymorphism of cranio-facial abnormalities is noted in the literature leonardi on 28 cases found hypertelorism in 50\% of cases, $36 \%$ nasal depression, $30 \%$ occipital prominence, $22 \%$ microgniathia. The palpebral cleft and coloboma cited in the literature were absent in the same case as in Herman's [10]. In the literature, the male sex predominates with $69 \%$. Delay in 
psychomotor development was found in $84 \%$ of patients in the MS PARADES series [8]. Hypertelorism is frequently cited by the authors, $80.7 \%$ according to MS PARADES [8] was present in our patient. In addition to these criteria proposed by Leonardi [7], some authors have reported other malformations. Thus KOSAK [11] described 2 cases with hypospadias and hypotonia. Atresia of the anus with perianal fistula and bilateral hydro nephrosis has been reported by Orstavik [12]. Zankl [13] reported secondary hypogammaglobulinemia due to loss from the gastrointestinal tract and with amelogenesis imperfecta. Musculoskeletal anomalies have been noted by some authors [2] [7] [13] [14] Inbreeding, noted in our case, has been reported by some authors [12] [15]. The prognosis depends on the severity of the cardiac and cerebral abnormalities [10] our patient's death occurred at home and was probably due to the severity of the cardiac abnormalities (single heart). Mortality reaches 52\% Leonardi) [7].

\section{Conclusion}

Ritscher-Schinzel syndrome is a rare congenital disease with poor prognosic because of the multiplicity of affected organs.

\section{Conflicts of Interest}

The authors declare no conflict of interest.

\section{References}

[1] Craft, E., Wildig, C.E. and Crow, Y.J. (2010) 3C Syndrome. American Journal of Medical Genetics Part A, 152, 1026-1027. https://doi.org/10.1002/ajmg.a.32820

[2] Descipio, C., Schneider, L., Young, T.L., Wasserman, N., Yaeger, D., Lu, F., et al. (2005) Subtelomeric Deletions of Chromosome 6p: Molecular and Cytogenetic Characterization of Three New Cases with Phenotypic Overlap with Ritscher-Schinzel (3C) Syndrome. American Journal of Medical Genetics Part A, 134, 3-11. https://doi.org/10.1002/ajmg.a.30573

[3] Ritscher, D., Schinzel, A., Boltshauser, E., Briner, J., Arbenz, U. and Sigg, P. (1987) Dandy-Walker (like) Malformation, Atrioventricular Septal Defect and a Similar Pattern of Minor Anomalies in 2 Sisters: A New Syndrome. The American Journal of Medical Genetics, 26, 481-491. https://doi.org/10.1002/ajmg.1320260227

[4] Gorlin, B.C.D., Robert, J., Cohen Jr., M. and Hennekam, R.C.M. (2001) Syndromes of the Head and Neck. Oxford Monographs on Medical Genetics, No. 42.

[5] Verloes, A., Dresse, M.F., Jovanovic, M., Dodinval, P. and Geubelle, F. (1989) 3C Syndrome: Third Occurrence of Cranio-Cerebello-Cardiac Dysplasia (Ritscher-Schinzel Syndrome). Clinical Genetics, 35, 205-208. https://doi.org/10.1111/j.1399-0004.1989.tb02929.x

[6] Deepika, G., Raghoji, C.R., Ashwini, R.C. and Guruprasad, G. (2017) A Case of Ritscher-Schinzel Syndrome or 3C Syndrome. International Journal of Contemporary Pediatrics, 4, 1122-1123. https://doi.org/10.18203/2349-3291.ijcp20171742

[7] Leonardi, M.L., Pai, G.S., Wilkes, B. and Lebel, R.R. (2001) Ritscher-Schinzel Cranio-Cerebello-Cardiac (3C) Syndrome: Report of Four New Cases and Review. American Journal of Medical Genetics, 102, 237-242.

https://doi.org/10.1002/ajmg.1449 
[8] Pira-Paredes, S.M., Montoya-Villada, J.H., Franco-Restrepo, J.L., Moncada-Vélez, M. and Cornejo, J.W. (2017) A Phenotypic Description of 26 Patients with Ritscher-Schinzel Syndrome (Cranio-Cerebelle-Cardiac Dysplasia or 3C Syndrome). Revue Neurologique, 64, 481-488. https://doi.org/10.33588/rn.6411.2016469

[9] Konya, M.N., Elmas, M., Erginoglu, S.E. and Yesil, M. (2015) A Rare Case of 3C Disease: Ritscher-Schinzel Syndrome Presenting with Recurrent Talipes Equinovarus. International Journal of Surgery Case Reports, 7, 130-133. https://doi.org/10.1016/j.ijscr.2014.10.098

[10] Herman, T.E. and Siegel, M.J. (2008) Ritscher-Schinzel Cranio-Cerebello-Cardiac Syndrome. Journal of Perinatology, 28, 715-718. https://doi.org/10.1038/jp.2008.80

[11] Kosaki, K., Curry, C.J., Roeder, E. and Jones, K.L. (1997) Ritscher-Schinzel (3C) Syndrome: Documentation of the Phenotype. American Journal of Medical Genetics, 68, 421-427.

https://doi.org/10.1002/(SICI)1096-8628(19970211)68:4<421::AID-AJMG10>3.0.C $\underline{\mathrm{O} ; 2-\mathrm{U}}$

[12] Orstavik, K., Bechensteen, A., Fugelseth, D. and Orderud, W. (1998) Sibs with Ritscher-Schinzel (3C) Syndrome and Anal Malformations. American Journal of Medical Genetics, 75, 300-303.

https://doi.org/10.1002/(SICI)1096-8628(19980123)75:3<300::AID-AJMG15>3.0.C O;2-T

[13] Zankl, A., Gungor, T. and Schinzel, A. (2003) Cranio-Cerebello-Cardiac (3C) Syndrome: Follow-Up Study of the Original Patient. American Journal of Medical Genetics, 118, 55-59. https://doi.org/10.1002/ajmg.a.10233

[14] Wheeler, P.G., Sadeghi-Nejad, A. and Elias, E.R. (1999) The 3C Syndrome: Evolution of the Phenotype and Growth Hormone Deficiency. American Journal of Medical Genetics, 87, 61-64.

https://doi.org/10.1002/(SICI)1096-8628(19991105)87:1<61::AID-AJMG12>3.0.CO; 2-K

[15] Marles, S.L., Chodirker, B.N., Greenberg, C.R. and Chudley, A.E. (1995) Evidence for Ritscher-Schinzel Syndrome in Canadian Native Indians. American Journal of Medical Genetics, 56, 343-350. https://doi.org/10.1002/ajmg.1320560402 